\title{
Analisis Finansial Perbanyakan Benih Jagung Hibrida
}

\author{
Adri, Mildaerizanti dan Suharyon \\ Balai Pengkajian Teknologi Pertanian (BPTP) Jambi \\ Jln.Samarinda Paal Lima, Kota Baru Jambi
}

Email :adeiaatjmb@gmail.com

\begin{abstract}
ABSTRAK
Kebutuhan terhadap jagung semakin meningkat, baik untuk pangan, pakan ternak, maupun bahan baku industri. Hal ini menjadi peluang sekaligus tantangan bagi pemerintah dalam peningkatan produksi jagung menuju swasembada berkelanjutan. Varietas unggul merupakan salah satu komponen yang dapat meningkatkan hasil dengan nyata, varietas hibrida memiliki potensi hasil lebih tinggi dibanding komposit sehingga penggunaan benih jagung hibrida mampu meningkatkan hasil jagung persatuan luas panen. Badan Penelitian dan Pengembangan Pertanian (Balitbangtan) telah menghasilkan varietas-varietas jagung hibrida dengan potensi hasil yang tinggi, yang tidak kalah bersaing dengan jagung hibrida swasta lainnya, hanya saja belum terdiseminasi dengan baik. Guna memperoleh nilai tambah bagi petani dan terdesiminasinya benih jagung Balitbangtan, maka dilakukan rintisan penangkaran benih jagung hibrida tingkat petani. Penelitian dilaksanakan di Desa Rawa Medang, Kecamatan Batang Asam, Kabupaten Tanjung Jabung Barat tahun 2017 seluas 1 ha. Rintisan ini dikemas dalam Model Sekolah Lapang Kedaulatan Pangan Terintegrasi Desa Mandiri Benih Jagung. Hasil penelitian diperoleh benih jagung sebanyak 1 ton/ha. Usahatani perbanyakan benih jagung hibrida ini layak dan menguntungkan secara ekonomi, hal ditunjukkan oleh nilai R/C 1,69, TIP $591 \mathrm{~kg} / \mathrm{ha}$ dan TIH Rp 14.775/kg. dilihat dari biaya produksi maka biaya tenaga kerja lebih tinggi 14,8 \% dibandingkan biaya untuk pembelian saprodi.

Kata Kunci : Rintisan, Penangkar, Benih, Jagung Hibrida
\end{abstract}

\section{PENDAHULUAN}

Jagung merupakan komoditas pangan ke dua penting setelah padi yang memiliki peran strategis dalam sistem ketahanan pangan dan penggerak perekonomian nasional. Jagung dibutuhkan tidak saja sebagai bahan pangan, namun juga bahan baku pakan ternak, industri makanan dan bahan bakar alternative. Kebutuhan terhadap jagung diproyeksikan akan terus meningkat seiring dengan terus bertambahnya jumlah penduduk, peningkatan pengetahuan tentang gizi dan industri.

Pemerintah berupaya meningkatkan produksi jagung untuk memenuhi kebutuhan dalam negeri. Arah dan sasaran peningkatan produksi ditujukan untuk pencapaian swasembada berkelanjutan guna mencapai kedaulatan pangan. Berbagai upaya dilakukan untuk peningkatan produksi diantaranya adalah penggunaan varietas unggul dan benih bermutu. Penggunaan varietas unggul memberikan kontribusi yang signifikan dalam peningkatan hasil persatuan luas, komponen utama dalam pengendalian hama dan penyakit serta cekaman lingkungan lainnya, karena itu menurut Suriadikarta dan Wiwik (2004) varietas unggul merupakan teknologi yang mudah diadopsi petani dan murah serta berkelanjutan.

Penggunaan benih unggul merupakan kunci utama untuk peningkatan produktivitas jagung. Dalam kaitan ini pemerintah mendorong penggunaan benih jagung hibrida unggul 
karena memiliki tingkat produktivitas yang tinggi. Sampai saat ini tingkat penggunaan benih jagung hibrida masih rendah yaitu baru sekitar 56\% dari total pertanaman (Dirjen Tanaman Pangan, 2016). Rendah tingkat penggunaan benih jagung hibrida ini antara lain disebabkan harganya relatif tinggi sehingga tidak terjangkau oleh sebagaian besar petani. Selain masalah harga, distribusi benih jagung hibrida juga belum meluas. Padahal penyediaan benih bermutu berperan penting dalam menentukan tingkat hasil yang akan diperoleh (Nugraha dan Hidayat, 2000). Pertanaman jagung hibrida yang ada di lapangan baik pertanaman jagung dari program pemerintah maupun mandiri petani itu merupakan jagung hibrida yang benihnya berasal dari luar daerah, yaitu benih yang dihasilkan oleh pihak swasta. Dengan harga benih per kilonya relatife mahal berkisar Rp. $45.000-110.000$

Benih adalah tanaman atau bagiannya yang digunakan untuk memperbanyak dan/ atau mengembangbiakkan tanaman pangan (Permentan, 2014). Benih merupakan cikal bakal kehidupan tanaman karena itu benih sangat menentukan produksi tanaman (Sudjindro, 2009). Benih merupakan faktor penentu dalam meningkatkan produktivitas tanaman (MacRobert et al., 2014), karena itu harus bermutu dan berkualitas. Penggunaan benih berkualitas meningkatkan hasil hingga 15-25\% (Roy, 2014). Benih hibrida diketahui memiliki potensi hasil lebih tinggi dibanding benih komposit, untuk itu penggunaan benih hibrida diharapkan dapat meningkatkan hasil jagung nasional.

Saenong et al., (2016) terdapat tiga hal penting yang berkaitan dengan kualitas benih yaitu: (1) teknik produksi benih berkualitas; (2) teknik mempertahankan kualitas benih yang telah dihasilkan serta pendistribusian; dan (3) teknik deteksi atau mengukur kualitas benih. Selanjutnya, tiga kriteria kualitas benih yang perlu diketahui adalah: (a) kualitas genetik, yaitu kualitas benih yang ditentukan berdasarkan identitas genetik yang telah ditetapkan oleh pemulia dan tingkat kemurnian dari varietas yang dihasilkan, identitas benih yang dimaksud tidak hanya ditentukan oleh tampilan benih, tetapi juga fenotipe tanaman; (b) kualitas fisiologi, yaitu kualitas benih yang ditentukan oleh daya berkecambah/daya tumbuh dan ketahanan simpan benih; (c) kualitas fisik, ditentukan oleh tingkat kebersihan, keseragaman biji dari segi ukuran maupun bobot, kontaminasi dari benih tanaman lain atau biji gulma, dan kadar air.

Benih memiliki peran strategis sebagai sarana pembawa teknologi baru, berupa keunggulan yang dimiliki diantaranya : 1) daya hasil tinggi, 2) tahan terhadap hama dan penyakit, sehingga mendukung pola tanam dan program pengendalian hama terpadu, 3) umur genjah, untuk meningkatkan indeks pertanaman, dan 4) keunggulan mutu hasil panen, sehingga sesuai dengan selera konsumen (Nugraha, 2013).

Sistem perbenihan dapat didefinisikan sebagai peraturan-peraturan yang harus diikuti dan program yang harus dilaksanakan untuk mencapai produksi dan distribusi benih dengan kualitas dan kuantitas yang direncanakan (Douglas, 1980). Sistem perbenihan memiliki subsistem mikro dan subsistem makro. Subsistem mikro lebih bersifat teknis lapangan produksi, sedangkan subsistem makro lebih berwawasan pada kebijakan dan hubungannya 
dengan di luar industri perbenihan. Wawasan subsistem makro meliputi sub-subsistem sektoral, infrastruktural, komoditas, dan plasma nutfah. Wawasan subsistem mikro meliputi sub-subsistem produksi di lapangan, pengolahan, penyimpanan, analisis mutu, penanganan, dan pemasaran Sudjindro (2009).

Menurut Louwaars dalam Roesmiyanto \& Sumarno (1998) sistem produksi benih dapat dibagi menjadi dua, yaitu sistem produksi benih formal dan sistem produksi benih lokal atau informal. Sistem produksi benih formal mencakup kesatuan program antara perakitan varietas unggul, produksi benih bermutu, pemasaran serta distribusi benih, dilakukan oleh tenaga-tenaga profesional, dengan mengikuti aturan-aturan yang berlaku, serta adanya jaminan mutu benih yang dibeli oleh petani. Sedangkan dalam produksi benih informal (lokal) penyediaan benih dilakukan dalam wilayah yang terbatas dan dilakukan oleh petani untuk kebutuhan sendiri dengan tujuan penyediaan benih setiap musim tanam secara praktis, tanpa mengikuti peraturan yang ada.

Petani penangkar benih, baik perorangan maupun kelompok, memiliki peran yang penting dalam proses diseminasi varietas unggul yang dihasilkan oleh lembaga penelitian (Sayaka et al., 2015). Pembinaan calon petani penangkar untuk meningkatkan mutu dan ketersediaan benih dalam satu kawasan pengembangan pertanian dapat menjadi sarana dalam meningkatkan kemandiriannya terhadap pangan. Petani penangkar menjadi mampu berdaulat untuk memenuhi kebutuhan benih di kawasan pengembangan secara mandiri melalui benih yang diproduksinya.

Tujuan penelitian ini adalah untuk menumbuh kembangkan penangkaran benih jagung Balitbangtan dan meningkatkan nilai tambah usahatani jagung petani.

\section{METODOLOGI/PROSEDUR PENELITIAN}

Penelitian dilaksanakan di Desa Rawa Medang, Kecamatan Batang Asam, Kabupaten Tanjung Jabung Barat, Provinsi Jambi tahun 2017. Data input-output produksi benih jagung Hibrida Bima Uri 20 diperoleh dari kegiatan Model Sekolah Lapang Kedaulatan Pangan Terintegrasi Desa Mandiri Benih Jagung.

\section{Teknik Produksi Benih Jagung Hibrida Bima Uri 20}

Lokasi penelitian terisolasi dari pertanaman varietas jagung lain dengan jarak $500 \mathrm{~m}$ dan jarak umur minimal 3 minggu. Persiapan lahan dimulai dengan cara membersihkan lahan dari sisa-sisa tanaman dan gulma, kemudiaan tanah dibajak 2 kali dan dilanjutkan dengan garu/sisir sampai tanah rata. Kebutuhan benih jantan $5 \mathrm{~kg} / \mathrm{ha}$ dan betina $15 \mathrm{~kg} / \mathrm{ha}$. Benih jantan ditanam 3 hari lebih awal, tujuannya supaya keluarnya malai pada induk jantan bersamaan dengan keluarnya rambut pada induk betina. Penanaman menggunakan alat tugal dengan jarak tanam $20 \mathrm{~cm}$ dalam barisan dan $75 \mathrm{~cm}$ antar barisan. Sebelum tanam benih diberi fungisida metalaksil sebanyak $2 \mathrm{~g}$ bahan aktif / kg benih dicampur air sebanyak $10 \mathrm{ml}$. 
Perbandingan jumlah baris induk tanaman jantan dan betina 1:3 (1 baris tanaman jantan dan 3 baris tanaman betina).

Dosis pupuk yang diberikan per hektar lahan adalah urea $400 \mathrm{~kg}, \mathrm{SP} 36200 \mathrm{~kg}, \mathrm{KCl}$ $150 \mathrm{~kg}$, Boron $6 \mathrm{~kg}$, serta kompos 1 ton. Kompos diberikan sebagai penutup lubang tanam. Pupuk dasar diberikan pada umur 7 hari setelah tanam (hst) dengan komposisi $30 \%$ Urea, 50\% KCL, SP 36 dan Boron seluruhnya. Pupuk ditugal di samping tanaman dengan jarak 5 $\mathrm{cm}$. Pupuk susulan $70 \%$ Urea dan 50\% KCL diberikan umur 30 hst atau setelah penyiangan dan pembumbunan. Penyiangan dilakukan dua kali yaitu umur 15 hst dan 28 hst. Pengendalian gulma dilakukan secara kimia selektif dan manual. Pengendalian hama penyakit dilakukan sesuai prinsip PHT. Pelaksanaan rouguing. Rouguing adalah kegiatan mengidentifikasi dan menghilangkan tanaman yang menyimpang (Suhartina, et al., 2012). Rouguing dilakukan saat pertumbuhan vegetatif, generatif dan prosessing hasil, dilakukan sesuai kriteria dalam Tabel 1.

Tabel 1. Kriteria Seleksi / Rouguing yang dilakukan

\begin{tabular}{lll}
\hline \multicolumn{1}{c}{ Parameter } & \multicolumn{1}{c}{ Kriteria Seleksi } & Keputusan \\
\hline Vigor tanaman roguing I (2-4 & Kerdil, lemah, warna pucat, bentuk tanaman & Tanaman \\
mst) & $\begin{array}{l}\text { menyimpang, tumbuh di luar barisan, terserang } \\
\text { penyakit, letak tanaman terlalu rapat. }\end{array}$ & dicabut \\
Berbunga roguing II (7-10 & $\begin{array}{l}\text { Terlalu cepat/lambat berbunga, malai tidak normal, tidak } \\
\text { berambut, tidak bertongkol. }\end{array}$ & Tanaman \\
mst) & Pilih yang kedudukan tongkolnya di tengah-tengah & Tipe simpang \\
Posisi Tongkol (2 minggu & batang, tongkol tidak bercabang (tipe simpang). & dipanen awal \\
sebelum panen & Tanaman sehat, telah ditandai terpilih, bentuk tongkol & Dipanen \\
Panen & utuh. & Dipilih \\
& Kelobot menutup 1-3 cm dari ujung tongkol, kelobot & Pilih skor 1-3 \\
Penutupan tongkol & melekat kuat dan rapat. & Dipilih yang \\
Kualitas tongkol per famili & Skoring penampilan tongkol: skor 1 baik dan skor 5 & seragam \\
\hline
\end{tabular}

\section{Sumber : Balit Serealia Maros}

Kemudian dilakukan detasseling yaitu pencabutan/penghilangan bunga jantan pada induk tanaman betina. Hal ini untuk mencegah terjadi penyerbukan sendiri (inbreeding). Detasseling dilakukan ketika tassel keluar dari daun bendera namun sebelum serbuksari mekar (MacRobert, et al., 2014). Proses detasseling dilakukan selama pembungaan setiap hari dalam masa 12 - 14 hari.

Panen dilakukan setelah kelobot mengering berwarna kecoklatan (biji telah mengeras dan mulai membentuk lapisan hitam (black layer) minimal 50\% di setiap barisan biji dengan kadar air biji sekitar 30\%. Kemudian dilakukan penjemuran, seleksi tongkol dan pemipilan dan penjemuran ulang sampai kadar air mencapai 10-12\%. Penjemuran dilakukan selama 3 jam per hari. 


\section{Analisis Finansial Perbanyakan Benih Jagung Bima Uri 20}

Untuk menganalisis kelayakan usahatani perbanyakan benih jagung dikumpulkan dan ditabulasi semua data input dan output produksi, yakni jumlah, harga, dan upah sarana produksi yang digunakan (benih, pupuk, obat-obatan), tenaga kerja (pengolahan tanah, tanam, pemupukan, penyiangan, penyemprotan, rouqing, tasseling, panen dan prosessing hasil.

Analisis dilakukan terhadap analisis parsial usahatani dilakukan (Soekartawi, 1995), analisis titik impas produksi (TIP) dan titik impas harga (TIH) (Setiawan, 2008). Analisis parsial usahatani perbanyakan benih jagung ini bertujuan untuk melihat perbandingan (nisbah) penerimaan dan biaya serta kelayakan usaha. Secara matematik dapat dituliskan sebagai berikut :

$\mathrm{a}=\mathrm{R} / \mathrm{C}, \mathrm{R}=\mathrm{Py} . \mathrm{Y}, \quad \mathrm{C}=\{(\mathrm{Py} . \mathrm{Y}) /(\mathrm{FC}+\mathrm{VC})\}$

Dimana : $\mathrm{R}=$ penerimaan; $\mathrm{C}=$ biaya; $\mathrm{Py}=$ harga output; $\mathrm{Y}=$ output

$\mathrm{FC}=$ biaya tetap; $\mathrm{VC}=$ biaya variable.

Break Event Point (BEP) adalah suatu keadaan dimana dalam suatu usahatani tidak mendapat untung maupun rugi / impas (penghasilan = total biaya). (Setiawan, 2008). Break Event Point (BEP) yang dianalisis adalah titik impas produksi (TIP) dan titik impas harga (TIH). Dengan mempelajari hubungan antara biaya produksi, volume penjualan, maka dapat diketahui tingkat keuntungan serta kelayakan usahatani perbanyakan benih jagung hibrida Bima Uri 20. Salah satu teknik dalam mempelajari hubungan antara biaya, penerimaan dan volume produksi adalah dengan menghitung titik impas produksi (Break Even Yield) dan titik impas harga (Break Even Price).

Untuk efisiensi produksi, maka analisis titik impas produksi dan titik impas harga sangat penting. Dengan alat analisis ini dapat diketahui pada tingkat produktivitas berapa usahatani memperoleh keuntungan, keuntungan normal ataupun mengalami kerugian. Analisis titik impas menghasilkan gambaran jumlah dan harga minimum yang akan diproduksi (Setiawan, 2008). Titik Impas Produksi (TIP) dan Titik Impas Harga (TIH) dapat dirumuskan sebagai berikut:

TIP = Total Biaya Produksi / Harga Produksi, dan

$\mathrm{TIH}=$ Total Biaya Produksi / Jumlah Produksi

\section{HASIL DAN PEMBAHASAN}

Usaha tani perbanyakan benih jagung Hibrida Bima Uri 20 memberikan hasil dalam bentuk benih yaitu 1 ton/ha. Hasil yang diperoleh ini masih rendah dibandingkan dengan potensi atau rata-rata hasil perbanyakan yang pernah dilakukan di kawasan sentra jagung seperti Sulawesi maupun Nusa Tenggara Barat (NTB), yaitu diatas 2 ton/ha (http://www.swadayaonline.com/artikel/292/Panen-Benih-F1-Jagung-Hibrida-Bima-20-URIBalitbangtan/. Rendahnya hasil yang diperoleh disebabkan oleh persentase tumbuh tanaman 
induk betina yang rendah yaitu $<60 \%$. Upaya penyulaman dilakukan terhadap tetua betina. Benih tetua betina direndam kemudian diperam setelah muncul titik tumbuh baru ditanam untuk mempercepat perkecambahan. Pada saat tanaman induk jantan mengeluarkan malai (bunga jantan) dilakukan penyimpanan malai di lemari pendingin. Menurut Poehlman (1987) cit. Maintang dan Nurdin (2013) serbuksari dapat dipelihara agar tetap hidup selama 7 - 10 hari dengan mengoleksi malai yang sebelumnya baru melepaskan serbuksari dan menyimpannya di lemari pendinginan. Setelah rambut pada tetua betina siap dibuahi maka dilakukan penyerbukan secara manual (Komunikasi pribadi dengan DR. M. Azrai Balit Serealia, April 2017). Pengelolaan serbuk sari untuk produksi benih hibrida sudah dilakukan pada berbagai tanaman di Indonesia (Agustin et al., 2014; Harliani et al., 2014; Rahmi, 2016; Palupi et al., 2017; dan Fariroh et al., 2017). Namun hasil penyerbukan ini kurang efektif sehingga tongkol-tongkol yang dihasilkan banyak yang tidak berisi, sehingga produksi benih masih rendah. Disamping itu, perbanyakan benih jagung Hibrida Bima Uri 20 ini merupakan pengalaman pertama bagi petani penangkar. Petani memang selama ini sudah terbiasa bertanam jagung tetapi jagung yang ditanam adalah jagung manis (sweet corn).

Dilihat dari indikator imbangan antara penerimaan dengan biaya $(\mathrm{R} / \mathrm{C}>1)$ maka kegiatan perbanyakan benih jagung Hibrida Bima Uri 20 ini layak untuk diusahakan. R/C 1,69, sehingga usahatani memberikan keuntungan sebesar 69\%. Input produksi tenaga kerja lebih tinggi dibandingkan dengan biaya untuk pembeliaan sarana produksi sebesar Rp 2.185.000,- . biaya yang dikeluarkan untuk tenaga kerja sebesar Rp 8.480,000 atau 57,4\% \% dari total biaya produksi, sedangkan biaya untuk input saprodi sebesar Rp 6.295.000 atau sebesar $42,6 \%$ dari total biaya produksi. Biaya produksi perbanyakan benih jagung jauh lebih tinggi dibandingkan biaya produksi jagung konsumsi, terutama biaya untuk harga benih tetua jantan dan tetua betina, pembeliaan pupuk, biaya pencabutan bunga jantan pada tanaman betina (detasseling), penyiangan, pembumbunan, rouqing dan prosessing hasil. 
Tabel 2. Input Produksi Perbanyakan Benih Jagung Hibrida Bima URI 20 Desa Rawa Medang, Kecamatan Batang Asam, Tanjung Jabung Barat tahun 2017 (Rp/ha)

\begin{tabular}{|c|c|c|c|c|}
\hline Uraian & Satuan & Jumlah & $\begin{array}{l}\text { Harga satuan } \\
\text { (Rp) }\end{array}$ & Biaya (Rp) \\
\hline \multicolumn{5}{|l|}{ Saprodi } \\
\hline Benih tetua jantan & $\mathrm{Kg}$ & 5 & 145.000 & 725.000 \\
\hline Benih tetua betina & $\mathrm{Kg}$ & 15 & 115.000 & 1.725 .000 \\
\hline Pupuk Urea & Zak & 8 & 225.000 & 920.000 \\
\hline Pupuk TSP & Zak & 4 & 120.000 & 480.000 \\
\hline Pupuk KCl & Zak & 3 & 290.000 & 870.000 \\
\hline Pupuk Mikro Boron & $\mathrm{Kg}$ & 8 & 25.000 & 200.000 \\
\hline Kompos & Karung & 25 & 35.000 & 875.000 \\
\hline Insektisida & Liter & 1 & 150.000 & 150.000 \\
\hline ZPT & Liter & 1 & 200.000 & 2000.000 \\
\hline Sub.total I & & & & 6.295 .000 \\
\hline \multicolumn{5}{|l|}{ Tenaga kerja } \\
\hline Pengolahan lahan & Paket & 1 & 1.200 .000 & 1.200 .000 \\
\hline Penanaman tetua jantan & HOK & 4 & 80.000 & 320.000 \\
\hline Penanaman tetua betina & $\mathrm{HOK}$ & 8 & 80.000 & 640.000 \\
\hline Pemupukan dasar & $\mathrm{HOK}$ & 6 & 80.000 & 480.000 \\
\hline Pemupukan susulan & HOK & 3 & 80.000 & 240.000 \\
\hline Penyiangan / bumbun & HOK & 26 & 80.000 & 2.080 .000 \\
\hline Pengendalian hama penyakit & HOK & 3 & 80.000 & 240.000 \\
\hline Rouqing & HOK & 2 & 80.000 & 160.000 \\
\hline Detaselling & $\mathrm{HOK}$ & 20 & 80.000 & 1.600 .000 \\
\hline Panen & HOK & 12 & 80.000 & 960.000 \\
\hline Prosessing hasil & HOK & 7 & 80.000 & 560.000 \\
\hline Sub.total II & & & & 8.480 .000 \\
\hline Total (I+II) & & & & 14.775 .000 \\
\hline Produksi benih berlabel $(\mathrm{kg})$ & 1.000 & & & \\
\hline Harga jual / kg & 25.000 & & & \\
\hline Penerimaan (Rp/ha) & 25.000 .000 & & & \\
\hline Keuntungan & 10.225 .000 & & & \\
\hline $\mathrm{R} / \mathrm{C}$ & 1,7 & & & \\
\hline $\mathrm{B} / \mathrm{C}$ & 0,7 & & & \\
\hline TIP (kg/ha) & 591 & & & \\
\hline $\mathrm{TIH}(\mathrm{Rp} / \mathrm{kg})$ & 14.775 & & & \\
\hline
\end{tabular}

Sumber : Data primer, Rawa Medang, Tanjung Jabung Barat (2017)

\section{Titik Impas Produksi (TIP) dan Titik Impas Harga (TIH)}

Titik Impas Produksi (TIP) teknologi perbanyakan benih jagung Hibrida Bima Uri 20 sebesar $591 \mathrm{~kg} / \mathrm{ha}$, ini menunjukan bahwa batas titik impas produksi sebesar $591 \mathrm{~kg} / \mathrm{ha}$. Apabila produksi kurang dari $591 \mathrm{~kg} / \mathrm{ha}$ maka perbanyakan benih jagung Hibrida Bima Uri 20 akan mengalami kerugian dan apabila lebih besar dari $591 \mathrm{~kg} / \mathrm{ha}$ maka usahatani perbanyakan benih jagung hibrida Bima Uri 20 menguntungkan. Produksi yang diperoleh 
dalam penangkaran benih jagung hibrida Bima Uri 20 di Desa Rawa Medang sebanyak 1.000 $\mathrm{kg} /$ ha dengan demikian usahatani perbanyakan benih jagung hibrida ini menguntungkan.

Disamping melihat titik impas produksi, kita harus melihat indikator lainnya yaitu Titik Impas Harga (TIH). Pada teknologi introduksi Rp 14.775/kg dan harga benih yang dijual Rp Rp $25.000 / \mathrm{kg}$

\section{KESIMPULAN}

Dari hasil dan pembahasan dapat ditarik kesimpulan bahwa :

1. Penangkaran benih jagung hibrida layak dan menguntungkan diusahakan oleh petani pengkar

2. Penangkaran benih jagung hibrida Bima Uri 20 oleh petani penangkar akan mempercepat penyebaran varietas jagung hibrida karya anak negeri

3. Ketersediaan benih jagung hibrida ditingkat petani akan menguarngi biaya produksi karena harga jual benih jagung hibrida oleh petani jauh lebih murah dibandingkan harga jual benih jagung hibrida oleh swasta

4. Teknologi penangkaran benih jagung hibrida mampu dilaksanakan petani

\section{Daftar Pustaka}

Agustin, H., E.R. Palupi, M.R. Suhartanto.2014. Pengelolaan polen untuk produksi benih melon hibrida Sunrise Meta dan Oranye Meta. J. Hortikultura 24:32-41.

Arief, R. dan S Saenong. 2003. Ketahanan simpan benih jagung (Zea mays. L) dari beberapa takaran dan waktu pemberian kalium. Jurnal Stigma. Vol. XI (1): 1-5.

Badan Litbang Pertanian. 2016. Rencana Strategis Badan Litbang Pertanian 2015-2019.

Dirjen Tanaman Pangan. 2014. Pedoman Teknis Sekolah lapangan Pengelolaan Tanaman terpadu (SL-PTT) Padi dan Jagung Tahun 2014. Kementerian Pertanian Direktorat Jenderal Tanaman Pangan.

Dirjen Tanaman Pangan. 2016. Petunjuk Teknis Gerakan Pengembangan Jagung Hibrida. Direktorat Jenderal Tanaman Pangan. Kementerian Pertanian

Douglas J. 1980. Succesfull Seed Program.A Planning and Management Guide. Colorado, USA: Westview Press, Boulder.

Fadhly AF, Saenong S, Arief R, Tabri F, dan Koes F. 2010. Perakitan Teknologi Produksi Benih Jagung Hibrida Berumur Sedang (90-100 hari, hasil benih F1>2 t/ha). Laporan Akhir Program Insentif Riset Terapan. Maros: Balai Penelitian Tanaman Serealia. 67 hlm. 
Fariroh, Indri., E.R. Palupi dan F.C. Suwarno. 2017. Penyimpanan Serbuk Sari Jagung dan Potensinya untuk Produksi Benih Hibrida. J. Agron. Indonesia, Vol. 45(2):147-154

Harliani, E.N., E.R. Palupi, D.S. Wahyudin. 2014. Potensi penyimpanan serbuk sari dalam produksi benih hibrida mentimun (Cucumis sativus L.) varietas KE014. J. Hort. Indonesia 5:104-117.

Hirricks A., A. Rami., K. Laajaj., R. Choukr-Allah., S.E. Jacobsen., L. El Youssfi., and H. El Omari. 2012. Sweet Corn Water Productivity under Several Deficit Irrigation Regimes Applied during Vegetative Growth Stage using Treate Wastewater as Water Irrigation Source. World Academy of Sci. Eng. and Tech. 61: 840-847

Jia, S., C. Li, S. Dong, and J. Zhang. 2011. Effects of Shading at Different Stages after Anthesis on Maize Grain Weight And Quality At Cytology Level. Agricultural Sciences in China. 10 (1) : 58-69.

Koes, F. dan O. Komalasari. 2011. Pengaruh Waktu Tanam Induk Betina Terhadap Produktivitas dan Mutu Benih Jagung Hibrida. Seminar Nasional Serealia 2011. Hal 539-547

MacRobert, J.F., P. Setimela, J. Gethi and M.W. Regasa. 2014. Maize Hybrid Seed Production Manual.

Maintang dan M. Nurdin. 2013. PENGARUH WAKTU PENYERBUKAN TERHADAP KEBERHASILAN PEMBUAHAN JAGUNG PADA POPULASI SATP-2 (S2)C6. Jurnal Agribisnis Kepulauan. Volume 2 No. 2. Hal 94 - 108.

Malian AH. 2000. Analisis ekonomi usahatani dan kelayakan finansial teknologi pada skala pengkajian. Makalah disajikan dalam pelatihan Analisis Finansial dan Ekonomi bagi Pengembangan Sistem dan Usahatani Agribisnis Wilayah. Bogor, 29 November- 9 Desember 2000. 28 hal.

Marwoto dan Suharsono. 2008. Strategi Dan Komponen Teknologi Pengendalian Ulat Grayak (Spodoptera litura Fabricius) Pada Tanaman Kedelai. Jurnal Litbang Pertanian, Vol. 27 No. 4. 2008. Hal.131-136.

Nugraha, U.S. 2013. Perkembangan industri dan kelembagaan perbenihan padi. 30p.

Pakki, S. dan Adriani. 2015. Preferensi Ketahanan Dan Dinamika Infeksi Penyakit Bulai Pada Aksesi Plasma Nutfah Jagung Dalam Tiga Musim Tanam. Prosiding Seminar Nasional Serealia, 2015. http://balitsereal.litbang.pertanian.go.id/wpcontent/uploads/2018/01/15hp48.pdf :).

Peraturan Menteri Pertanian Nomor 02/Permentan/SR.120/1/2014 tentang Produksi, Sertifikasi dan Peredaran Benih Bina; 
Poehlman M.1987. Breeding Field Crops. Third Edition. An Avi Book. Van Nostrand Reinhold. New York. P.45.

Purwono dan Hartono, R. 2005. Bertanam Jagung Unggul. Penebar Swadaya. Jakarta

Palupi, E.R., R.M. Sidabutar, K. Wanafiah. 2017. Pollen drying and storage for hybrid seed production of cucumber (Cucumis sativus L.). Acta Hortic. 1151: 163-168.

Rao, M.S, Manimanjari D, Vanaja M, Rama Rao CA, Srinivas K, Rao VUM, Venkateswarlu B. 2012. Impact of elevated CO2 on tobacco caterpillar, Spodoptera litura on peanut, Arachis hypogeal. Journal of Insect Science Vol. 12 (103). Hal 1-10.

Rahmi, M. 2016. Aplikasi boron dan pengelolaan serbuk sari untuk produksi benih cabai hibrida IPB. Tesis. Sekolah Pascasarjana. Institut Pertanian Bogor. Bogor.

Roesmiyanto, Sumarno. 1998. Model usaha perbenihan kedelai informal di pedesaan. $D i$ dalam : Roesmiyanto, Sumarno dan Takhesi Nabeta, editor. Prosiding Lokakarya Sistem Produksi dan Peningkatan Mutu Benih Kedelai di Jawa Timur; Malang, 27 Juli 1998. Malang. Hal 42-52.

Saenong, S. dan Rahmawati. 2010. Penentuan Komposisi Tanaman Induk Jantan dan Betina Terhadap Produktivitas dan Vigor Benih F1 Jagung Hibrida Bima-5 . Prosiding Pekan Serealia Nasional, 2010. Hal 74-85. ISBN : 978-979-8940-29-3

Saenong, S., M. Azrai, R. Arief dan Rahmawati. 2016. Pengelolaan Benih Jagung. Dalam Jagung : Teknik Produksi dan Pengembangan. Balai Penelitian Tanaman Serealia. Maros. Hal 146-174.

Setiawan, D,H., dan Agus Andoko. 2008. Petunjuk Lengkap Budi Daya Karet. Kiat Mengatasi Permasalahan Praktis. Penerbit PT.Agro Media Pustaka

Sija, Patta. 2013. Peningkatan Produksi Benih Jagung Hibrida Melalui Optimalisasi Populasi Dan Rasio Tetua Jantan Betina. Sekolah Pascasarjana. Institut Pertanian Bogor. Bogor. Didownload dari https://repository.ipb.ac.id/jspui/bitstream/123456789/63489/1/2013 psi.pdf. 8 Oktober 2018]

Sonhaji, M.Y., M. Surahman, S. Ilyas dan Giyanto. 2013. Perlakuan Benih untuk Meningkatkan Mutu dan Produksi Benih serta Mengendalikan Penyakit Bulai pada Jagung Manis. J. Agron. Indonesia. Vol. 41 (3) : 242-248.

Sudiakarta, D. A dan Wiwik. H, 2004. Teknologi Pengelolaan Lahan Sawah Bukaan Baru. Tanah Sawah dan Teknologi Pengelolaannya. Pusat Penelitian dan Pengembangan Tanah dan Agroklimat. Badan Penelitian dan Pengembangan Pertanian Departemen Pertanian. Hal 115-136. 
Sudjindro. 2009. Permasalahan dan implikasi system perbenihan. Buletin Tanaman tembakau, Serat dan Minyak Industri. Vol. 1 (2). Hal 92-100.

Suhartina, Purwantoro, Abdullah T., dan Novita N. 2012. Panduan Roguing Tanaman dan pemeriksaan benih kedelai. Kementerian Pertanian. Badan Penelitian dan Pengembangan Pertanian. Balai penelitian Tanaman Aneka Kacang dan Umbi. Malang

Sutopo, L. 2010. Teknologi benih. Fakultas Pertanian Universitas Brawijaya. 237 hal.

Syafruddin dan S. Saenong. 2005. Pengaruh pemupukan terhadap mutu benih jagung. Dalam Seminar dan Lokakarya Nasional Jagung 2005. Balai Penelitian Tanaman Serealia. Makasar_Maros. September 2005.

Syafruddin, Faesal, dan M. Akil. 2016. Pengelolaan Hara pada Tanaman Jagung. Dalam Jagung : Teknik Produksi dan Pengembangan. Balai Penelitian Tanaman Serealia. Maros. Hal 205-218.

Takdir, A.M., S. Sunarti, dan M.J. Mejaya. 2016. Pembentukan Varietas Jagung Hibrida. Dalam Jagung : Teknik Produksi dan Pengembangan. Balai Penelitian Tanaman Serealia. Maros. Hal. 74-95.

Thomison P. 2002. Cultural Practices for Optimizing Maize Seed Yields \& Quality. Seed Production Seminar Oct. 15 and 16. 2002. Pontificia Universidad Catolica de Chile. Ohio: Horticulture and Crop Science. Ohio State University

Tusi, A. dan R.A.B. Rosad. 2009. Aplikasi Irigasi Defisit Pada Tanaman Jagung (Deficit Irrigation Application on Corn Plant). Jurnal Irigasi - Vol. 4, (2), Hal. 120-130.

Widiarta, I.N., N.A. Subekti, A. Harsono, N. Nugrahaeni, Marwoto, T. Sundari, Y. Prayogo, M. Azrai, A.M. Adnan, R. Arief, M.Aqil, Bahtiar, A. Kus, H.T. Agustiwi. 2015. Pedoman Umum. Pengembangan Model Kawasan Mandiri Benih Padi, Jagung, Dan Kedelai. Badan Penelitian dan Pengembangan Pertanian. Kementerian Pertanian. Jakarta. 